\title{
CORRELATION BETWEEN PARENTING AND ANXIETY ON HIGHER ACHIEVER STUDENTS
}

\author{
Rini Sugiarti, Erwin Erlangga
}

Faculty of Psychology Universitas Semarang

\begin{abstract}
This research aims at testing empirically correlation between parenting and anxiety on higher achiever students. Hypothesis of the research is that there is correlation between parenting and anxiety on higher achiever students.This qualitative study was population study with subjects as many as 80 higher achiever students. Data were collected using scales, parenting scale and anxiety scale. Data were analyzed using product moment correlation. The result of the study shows that there was significant correlation between parenting and anxiety on higher achiever students with $r_{x y}=0.870$ and $(p<0.01)$ thus the hypothesis of this study was accepted.
\end{abstract}

\section{BACKGROUND}

The success of learning and teaching process can be seen from test result in the form of achievement given to students. It can be said that achievement is one of the parameters that can be used to measure learning success of students. The achievement is realized in the form of scores and numbers. To accomplish good achievement, it is common that students was demanded to study as well as they can.

In reality, based on the interview result taken randomly, most students said that they experienced anxiety although they had prepared themselves as well as they could. This anxiety, in fact, causes doubt when they will face a test. On the other side, higher achiever students also realize that parents are meaningful source of their success to reach their achievement. The parenting has made the higher achiever students felt being cared for, worthy, loved, and secure.

Children experience anxiety of being lost in facing Olympiad competition that makes their parents will be angry at them. The characteristics of this anxiety are muscle tension, difficulty sleeping, diarrhea, nightmare, over sweating and losing appetite. Children with light symptoms will try to avoid going to school by wasting their time doing something else when they will go to school, have problems with concentration at school, and go back home as soon as they can. 
Children with moderate symptoms will tend to be at home as often as possible instead of attending school, refuse to hang out with their friends when they are at home, and always be near their parents when they are at home. Meanwhile, children with rather severe symptoms usually will refuse to go to school.

\section{LITERATURE STUDY}

1. Anxiety

\section{a. Definition of anxiety}

Anxiety is one of emotions that mostly causes stress felt by many people. Anxiety is also called fear or nervous feeling (Greenberger, 2004: 209). Sensation of anxiety is often felt by almost all individuals. This feeling is typically characterized with fear, unease, and frequently comes with symptoms such as dizziness and sweating. In accordance with Barlow's statement (Durand and Barlow, 2006: 158), anxiety is a condition, mood that is marked by physical symptoms such as physical tension and worry about the future. An anxious individual may also feel restless. Anxiety is a form of unsteady feeling with some sort of fear to uncertain or unreal things (Kartono, 1986:21). Alwisol (2004:28) stated that anxiety is ego function to warn an individual about any possibilities of danger that may come so that the individual can prepare for an adaptive reaction.

Anxiety is a feeling experienced by an individual when thinking about something unpleasant that may happen (Priest, 1994: 10). Anxiety is a form of feeling that is not settled, and surrounded by some sort of fear to uncertain or unreal things (Kartono, 1986:21). Hurlock stated that anxiety is a form of worry, nervous, and other unpleasant feelings. Generally, those feelings are accompanied with lacking of confidence, inability, having low self esteems and inability to deal with problems. Nevid (2003: 163) stated that anxiety is an emotional condition that is marked with physiological arousal, unpleasant feeling of tense and apprehensive feeling that something bad will happen. In accordance with Murray's statement (1995:89), anxiety is an unpleasant emotional condition coming from unhappiness or emotional feeling that begin in low then gradually getting intentionally stronger. Anxiety is mainly caused by uncertain fear coming from continuous feeling that something bad will happen and, consequently, the individual having it experiences trouble sleeping, inability to feel relaxed, and frequently awaken along the night (Murray, 1995: 89). These are an awakening signal, warning for the coming danger that threatens and enables an individual to take 
action in order to overcome the threat (Kaplan, 2000: 3).

Based on the definitions of anxiety aforementioned, it can be concluded that anxiety is a feeling experienced by an individual when thinking that something unpleasant will happen.

\section{b. The symptoms of Anxiety}

Anxiety occurs because there is a threat that bothers an individual. Atkinson (2001: 413) explained that an individual having anxiety will experience physical problems such as trouble sleeping, unease, fatigue, dizziness, headache, and palpitating heart. In addition, the individual continuously feels afraid of the possibility of trouble and he/ she also experiences difficulty in concentrating or making decision.

Many people who feel anxious are very alert to physical symptoms such as restless, sweating palm, headache, and shortness of breath, palpitation and blushing cheek. (Greenberger, 2004: 209).

Symptoms of anxiety according to Abu Bakar (Risbiyantini, 2004: 15) are:

a. Physical symptoms such as restless, tense feeling, irritating, worry of what may happen, helplessness, losing attention, feeling useless, feeling depressed, losing passion, insecure, desire to run from reality, unease, and unable to adapt.

b. Physical symptoms such as rising blood pressure, cold hand and feet, sweating body, palpitating heart, sudden blushing on the face, frequent stomachache, difficulty in sleeping, easy to get headache, hard breathing and nausea.

c. Social symptoms such as the feeling of having no self worth, changes in self identity, fear of anything related to aging process, feeling of losing important role as a woman who gives birth, as well as the feeling of being useless.

d. Sexual symptoms such as low libido, difficulty in doing sexual intercourse, afraid of losing appeal and afraid of unable to give sexual satisfaction to the husband.

Anxiety symptoms according to Nevid (2003: 164) are:

a. Physical symptoms such as restless or nervousness, shaking hands or body, excessive sweating, dry mouth or throat, hard breathing, headache, difficult to swallow, diarrhea, flushing face, heart palpitating.

b. Behavioral symptoms such as avoidant behavior, clingy 
behavior, shaken out behavior.

c. Cognitive symptoms such as worrying about something, feeling disturbed by the fear of something that may happens in the future, belief that something horrible will happen, difficulty in concentrating.

Meanwhile here are psychological symptoms of anxiety according to Blackburn Davidson (www. klinis.wordpress.com):

a. Mood, that is a condition showing psychological uneasiness such as irritating, feeling so tense. Mood, which is a condition that shows physical uneasiness, such as irritating, tense feeling.

b. Mind, which is an erratic mind condition such as worry, difficulty in concentrating, empty mind, exaggerating threat, considering self to be very sensitive, feeling helpless.

c. Motivation, which is a drive to achieve something, such as avoid a certain situation, high dependence, desire to run from reality.

d. Restless behavior, which is an uncontrolled self condition such as nervous, high alertness, over sensitive and agitation.

e. Uncontrolled biological symptoms such as sweating, shaking, headache, palpitation, nausea, dry mouth.

According to Kaplan (2000:2), symptoms of anxiety are: headache, sweating, palpitations, stiffness on chest, light gastric problem, restlessness, inability to sit or stand for a quite long time.

Based on the previous descriptions, in this study, the symptoms of anxiety are:

a. Psychological symptoms such as tense feeling, irritating, worry of what may happen, helplessness, losing attention, feeling useless, feeling depressed, losing passion, insecure, desire to run from reality, unease, and inability to self adapt.

e. Physical symptoms such as raising blood pressure, cold hand and feet, sweating body, palpitation, sudden flushing face, frequent stomach ache, difficulty sleeping, easy to get headache, hard breathing and nausea.

\section{Parenting}

\section{a. Definition of Parenting}

Relationship with another individual is main thing in life (Engels, et al, 2001). 
Parenting is an action process and interaction between parents and children, in which both sides change each other as the children grow into an adult (Brooks, 2011). Parenting the way parents provide protection both physically and physiologically (Berns, 2004). Furthermore, Berns (2004) said that parents in a family are the main agent of socialization that is influencing to self development of higher achiever students (Guralnick, 2008; Mallinckrodt and Wei, 2005).

Based on the previous understanding, it can be concluded that parenting is the way parents provide protection both physically and psychologically to children.

\section{b. Characteristic of Parenting}

Cooperation in sharing parenting shows closeness and warmth with children (Caugh, et al, 2012; Santrock), which is identical of parenting. Moreover, parents giving parenting is also characterized by good cooperation with spouse in sharing parenting tasks (Santrock, 1995; Peterson, 2008), tolerance and willingness to respect children (Santrock, 1995), open a good communication, as well as showing closeness relation with children (Peterson, 2008). Slightly different form Peterson and Santrock, Wang, et al (2011) stated that parenting is shown by parenting in giving positive reinforcement to children and full of warmth when interacting with children (Cy, et al, 2001; Santrock, 1995).

Differently, Kazemi, et al (2010; Oravecz, et al 2008) highlighted that the role of control performing by parents and support to children are the forms of parenting. Oravecz also added that parents support or the ability to do parenting will make the children feel accepted and secure. This parenting is seen in the willingness to help, warmth given, as well as affection given to children. Furthermore, Luecken, et al (2013) described that besides warmth given, the forms of parenting to children include monitoring social function of children, trying to correct the children when they make inappropriate behavior, as well as guiding the children when they face a conflict.

Based on the previous description, the researchers concluded that parenting is shown in the following forms:

a. Cooperation with spouse in sharing parenting tasks, meaning that there is willingness to share in every parenting task,

b. tolerance to children, meaning that respect every attitude and behavior of children,

c. warmth in interaction with children, meaning that open 
positive communication in various situations in every interaction with children.

\section{RESEARCH METHOD}

\section{The Subject of The Research}

Subjects in this research are students of "IBU KIKI" course institution who joined academic competitions with the following criteria:

1. Students who have academic achievement

2. Students who participate in academic competition

\section{Instrument of Data Collecting}

Scale and achievement documents in "IBU KIKI" study course were used as data collecting instrument. Scale used was anxiety and patterns of parenting scales.

\section{Validity and Reliability}

a. Validity

The validity of this parameter applied product moment correlation technique by Karl Pearson and corrected using Part Whole correlation technique

b. Reliability

To search reliability of this parameter, alpha cronbach coefficient technique was used

\section{The Technique of Data Analysis}

Technique of statistical analysis used to test the hypothesis was correlation between parenting and anxiety on higher achiever students using Product Moment correlation technique.

\section{RESEARCH RESULT}

A. Result

1. Validity test

Research was conducted on October 2016 - December 2016. Scales that were spread were 80 exemplars, all eligible to be analyzed.

The testing of validity items was conducted using Product Moment technique that later was corrected using Part Whole correlation technique. Validity test is meant to identify which items are valid and later they will be used in the arrangement of research parameter.

1) Scale of parenting

Parenting scale was tested on to 30 respondents who are different from the respondents of the research as many as 80 respondents. Parenting scale which at first consisted as many as 50 items was reduced to 47 valid items, 3 items failed. The coefficient items ranged between 0.278 0.665 with 5 significance level. Valid and invalid data can be seen in the attachment.

2) Anxiety Scale

Anxiety scale was tested to 30 respondents who is different from the respondents of the research that was as many as 80 respondents. Anxiety scale which at first consisted of 26 items was 
reduced to 24 valid items, 2 items were invalid. The coefficient of the items ranged between $0.278-0.665$ with 5 significance level.

\section{B. Outcome Achieved}

The result of the research shows that there is significant correlation between parenting and anxiety of higher achiever students. Students who get authoritarian parenting style have higher anxiety when facing academic competition as much as $31 \%$. This result is in accordance with Ngalim Purwanto's finding (2007:104), stating that support, situation, and family condition also determine children's academic achievement. This research result is also in line with research result conducted by Yusniyah (2008) stating that there is correlation between parenting patterns and students academic achievement, and the application of democratic style of parenting can improve students' academic achievement because this democratic style parenting can help higher achiever students deal with academic competition well.

Achievement of students, which is represented by scores of study result, basically reflects how far the level of success that has been achieved by the students in reaching education goal. Accomplishing satisfactory achievement, besides learning, must also be supported with the proper implementation of parenting pattern. If parents implement improper parenting pattern, this will bring bad impact on the children particularly on their attitude and personality leading to affecting their academic achievement. Every parent certainly wants their children to be a smart, clever and well mannered student.

However, there are still many parents who do not realize that parenting style or pattern they implement has made the children feel anxious, their freedom being limited, even some of them do not feel loved by their parents. These feelings mostly influence their attitude, feeling, way of thinking, even intelligence. The way parents educate their children will influence the children personality so that ultimately it will also influence their academic achievement. In reality, most of the time students want maximal outcome but using improper way, such as cheating. They want good scores, yet they do not care with the process they must go through. They ignore the fact that to get good grades or scores and to be a student with achievement, the first thing they must do is to study hard.

\section{CONCLUSION AND SUGGESTION}

Based on the conclusion and discussion aforementioned, here are some suggestions: 
1. It is expected that parents implement democratic style of parenting in educating their children because democratic style parenting is believed and proven to be able to improve students' study achievement.

2. For the children/students, they should be open with their parents about problems that they face. They should also act positively and selectively to their parents' attitude. If parents have attitude that leads to permissive style of parenting, the children should not be bothered to initiate a communication so that their relationship can get better.

3. For the future researchers, it is suggested that they use other methods in conducting research about parenting patterns, as for example through deep interview on students and their parents although it is only for some parts, thus the information obtained can be various.

\section{REFERENCES}

Alwisol. 2004. Psikologi Kepribadian. Malang: UMM Press.

Atkinson. 2001. Pengantar Psikologi. Jilid 2. Batam: Interaksara.

Durand, V, M, dan David H. Barlow. 2006. Intisari Psikologi Abnormal. Yogyakarta: Pustaka Pelajar.
Manajemen Pikiran Metode Ampuh Menata Pikiran Untuk Mengatasi Depresi, kemarahan, Kecemasan, dan Perasaan Merusak Lainnya. Bandung: Kaifa PT. Mizan Pustaka.

Kartono. 1986. Psikologi Wanita: Wanita Sebagai Ibu dan Nenek. Jilid 2. Bandung: Alumni.

Mappiare, A. 1983. Psikologi Orang Dewasa. Surabaya: Usaha Nasional.

Nevid, J, S, dkk. 2003. Psikologi Abnormal. Jilid 1. Jakarta: Erlangga.

O' Brien, P. 1994. Menghadapi Masa Menopause Dengan Penuh Kebahagiaan. Alih Bahasa: Rita, S. S. Jakarta: Binarupa Akasara.

Priest, R, 1994. Bagaimana Cara Mencegah Dan Mengatasi Stres Dan Depresi. Semarang: Dahara Prize.

Syahraini, Karyono, Rohmatun. 2007. "Kecerdasan Emosional Dan Kecemasan Pramenopause Pada Wanita Di Rw IV dan XI Kelurahan Gebang Sari Semarang”. Jurnal Psikologi Proyeksi, Februari, II (01): 29-39.

Greenberger dan Padesky. 2004. 